\title{
ІНФОРМАЦІЙНІ АСПЕКТИ ТРАНСФОРМАЦЇ̈ ДЕРЖАВНОГО УПРАВЛІННЯ В УМОВАХ ТУРБУЛЕНТНОСТІ
}

\section{Панченко О. А.}

\section{ВСТУП}

Кінець 1990 -х - початок 2000-х років стали часом розвитку масової інформатизації, тобто організаційно забезпеченого процесу задоволення інформаційних потреб індивідів на основі впровадження інформаційно-комунікаційних технологій (далі - IКТ) у всіх сферах людської діяльності (державному управлінні, виробничому секторі економіки, освіті, охороні здоров'я) та в приватному житті громадян.

Безсумнівний успіх комп'ютеризації державного управління, судової і правоохоронної систем проявився в підвищенні оперативності та ефективності прийняття державними органами рішень. Виявився вірним i проголошений курс на формування інформаційного суспільства, тобто якісно нового рівня суспільного розвитку на основі високорозвиненої інформаційної інфраструктури, широкого доступу до інформації, збалансованого ринку інформаційних продуктів i підвищення питомої ваги сектору ІКТ в економіці.

Розвиток технологій збору й аналізу даних, обміну ними, управління виробничими процесами здійснюється на основі впровадження когнітивних технологій, їх конвергенції 3 нано- i біотехнологіями. Значне збільшення обсягу даних, джерелами i засобами поширення яких $є$ промислові та соціальні об'єкти, різні електронні пристрої, призводить до формування нового рівня наукомістких інформаційних технологій. Їх повсюдне застосування сприяє переходу до цифрової економіки.

Інформаційна сфера стала системоутворюючим чинником суспільного життя, тобто цілком обгрунтовано можна стверджувати, що в життєдіяльності суспільства вона грає не допоміжну роль, а одну $з$ ключових, у тому числі з погляду державної політики та державного управління. Своєю чергою, інформація стає важливим ресурсом суспільства і держави $\mathrm{i}$, як наслідок, суттєво зростає роль засобів масової інформації.

Проблематика, пов'язана 3 інформаційним супроводом державної політики та пошуком шляхів підвищення його ефективності, особливо актуалізована в сучасних соціально-політичних умовах, у зв'язку з чим 
дана тема має широкі перспективи для подальшого наукового розроблення в міждисциплінарних гуманітарних дослідженнях.

За всіма економічними, політичними, екологічними, культуральними, інформаційними ознаками людство вступило в епоху турбулентності, яка характеризується низкою важливих особливостей: плинність, нестійкість, невизначеність і яка ставить перед суспільством досі незвідані виклики. Серед науковців існує думка, що саме інформатизація суспільства призвела до прискорення появи нових тенденцій у світовому розвитку. Отже, вивчення сучасних інформаційних викликів $\epsilon$ актуальним завданням не тільки теоретичного характеру, а й практичного застосування у державному управлінні.

\section{1. Забезпечення державної інформаційної політики у сфері цифрової трансформації суспільства}

Стрімке наростання можливостей оперативного обміну економічною, науково-технічною, культурною, політичною, військовою та іншою інформацією є безсумнівним благом, великим досягненням цивілізації.

У третьому тисячолітті на тлі переходу людства від індустріальної цивілізації до цивілізації інформаційної інформація стала одним із головних чинників історичного прогресу. Вона має ключове значення для успішного функціонування всіх суспільних і державних інститутів, адекватної поведінки кожної окремої людини. Без інтенсивного обміну інформацією, постійного інформаційного зв'язку з навколишнім світом у принципі неможлива нормальна життєдіяльність людей.

Інформація - це відомості про навколишній світ і процеси, які протікають у ньому, сприймаються людиною або спеціальним пристроєм для потреб людини. Інформація необхідна кожному як умова й як засіб існування людини в суспільстві.

Особливе значення надається достовірності інформації. Це природна якість інформації, що розуміється як адекватне (не спотворене) відображення змісту життєвих ситуацій, виступає мірилом орієнтації й адаптації людини в житті ${ }^{1}$. Н. Вінер підкреслював, що інформація, яка отримується людиною, «координується мозком i нервовою системою; після накопичення, звірення і відбору вона приєднується до вже накопиченого запасу інформації, впливаючи на майбутні наші дії» ${ }^{2}$. Тому очевидно, що така інформація повинна бути достовірною. Достовірна інформація є основою прийняття органами держави правильних управлінських рішень.

1 Могилевский В.Д. Методология систем: вербальный подход. Москва : Экономика, 1999. 251 с.

${ }^{2}$ Винер Н. Кибернетика и общество. Москва : Изд-во иностр. лит., 1958. 200 с. 
Новий стан інформаційного суспільства як суспільства достовірних знань покликане забезпечити нову якість людської діяльності на основі створення «довірчого» інформаційного середовища. Разом із тим сучасний рівень технологічного розвитку створив небачені раніше можливості модифікувати зміст поширюваної інформації, змінювати іiї первісний зміст. Людина у цих умовах приймає змінений зміст інформації як справжнє і втрачає орієнтири в житті.

Головна мета сучасної державної інформаційної політики (формування суспільства знань) 3 урахуванням забезпечення таких національних інтересів: розвиток людського потенціалу; забезпечення безпеки громадян і держави; підвищення ролі країни у світовому гуманітарному і культурному просторі; розвиток вільної, стійкої та безпечної взаємодії громадян і організацій, органів державної влади, органів місцевого самоврядування; підвищення ефективності державного управління, розвиток економіки і соціальної сфери; формування цифрової економіки.

Досягнення головної мети і забезпечення національних інтересів в інформаційному просторі повинні здійснюватися шляхом реалізації таких пріоритетів:

a) формування інформаційного простору 3 урахуванням потреб громадян і суспільства в отриманні якісних та достовірних відомостей;

б) розвиток інформаційної і комунікаційної інфраструктури;

в) створення i застосування національних інформаційних i комунікаційних технологій, забезпечення їхньої конкурентоспроможності на міжнародному рівні;

г) формування нової технологічної основи для розвитку економіки i соціальної сфери;

д) забезпечення національних інтересів у сфері цифрової економіки.

Стан ІКТ в Україні можна оцінити так:

- темпи розвитку технологій створення, обробки і поширення інформації значно перевищили можливості багатьох людей в освоєнні і застосуванні знань. Більшість людей стали відірваними від інформації, що містить знання;

- розвиток комп'ютерної техніки та телекомунікаційних технологій сприяв зміщенню акцентів у сприйнятті навколишнього світу (особливо в мережі Інтернет) з наукового, освітнього і культурного на розважально-довідковий. Сформувалася нова модель сприйняття дійсності - так зване кліпове мислення, характерною особливістю якого $є$ масове поверхневе сприйняття інформації. Воно спрощує погляди людей на знання, сприяє формуванню нав'язаних моделей поведінки, що дає перевагу в досягненні економічних і політичних 
цілей тим державам i організаціям, яким належать технології поширення інформації.

Дані висновки виглядають далеко не оптимістично. Щоб змінити ситуацію, держава створює умови для формування простору знань i надання доступу до нього, вдосконалення механізмів поширення знань, їх застосування в інтересах особистості, суспільства і держави.

Формування простору знань здійснюється шляхом розвитку науки, реалізації освітніх та просвітницьких проєктів, створення для громадян загальнодоступної системи взаємопов'язаних знань і уявлень, забезпечення безпечного інформаційного середовища для дітей, підтримки традиційних (відмінних від доступних з використанням мережі Інтернет) форм поширення знань. Акцент на забезпеченні безпечного інформаційного середовища для дітей робиться не випадково, оскільки можливості мережевих технологій створюють спокуси отримувати інформацію, здатну завдати шкоди їх здоров'ю та розвитку.

Передбачається комплекс заходів переважно загальнокультурного i духовно-морального характеру, які повинні змінити орієнтири для отримання, обробки та використання знань. До них можна віднести заходи у сфері духовно-морального виховання громадян; реалізацію просвітницьких проєктів; удосконалення механізмів обміну знаннями; формування Національної електронної бібліотеки та інших державних інформаційних систем, що включають у себе об'єкти історичної, наукової та культурної спадщини; формування i розвиток правосвідомості громадян та їх відповідального ставлення до використання інформаційних технологій; забезпечення створення і розвитку систем нормативно-правової, інформаційно-консультативної, технологічної та технічної допомоги у виявленні, попередженні, запобіганні та відображенні загроз інформаційній безпеці громадян і ліквідації наслідків їх прояву; вдосконалення механізмів обмеження доступу до інформації, поширення якої заборонено нормативними актами, та іiі видалення; вдосконалення механізмів законодавчого регулювання діяльності засобів масової інформації, Інтернет-телебачення, новинних агрегаторів, соціальних мереж, сайтів у мережі Інтернет, месенджерів. Водночас існує необхідність ужиття заходів для підтримки традиційних засобів поширення інформації (радіо-, телемовлення, друковані засоби масової інформації, бібліотеки).

Важливим пріоритетом є формування цифрової економіки та освіти iii екосистеми - партнерства організацій, що забезпечує постійну взаємодію їхніх технологічних платформ, прикладних Інтернетсервісів, аналітичних систем, інформаційних систем органів державної влади, організацій і громадян. 
Передумовою актуалізації названого пріоритету $\epsilon$ воістину революційний стрибок у розвитку високих наукоємних інформаційних технологій, що створюються переважно на стику різних сфер передових знань (нано- та біотехнології, оптичні технології, когнітивні технології, технології штучного інтелекту, альтернативні джерела енергії та ін.).

Уважається, що термін «цифрова економіка» (digital economy) в 1995 р. увів учений із Массачусетського технологічного інституту Ніколас Негропонте. Сьогодні цей термін використовується як на рівні державної політики, так і на прикладному рівні (електронна взаємодія, електронний документообіг, торгові операції в мережі Інтернет i система електронних платежів, телемедицина, електронне середовище системи освіти, Інтернет-банкінг та ін.).

Цифрова економіка являє собою господарську діяльність, ключовим фактором виробництва в якій є величезні масиви даних у цифровій формі (великі дані) й яка сприяє розвитку інформаційної інфраструктури держави, формування нової технологічної основи для соціальної та економічної сфер 3 урахуванням потреб громадян i суспільства в отриманні якісних та достовірних відомостей.

Цифрова економіка представлена такими рівнями, які у тісній взаємодії впливають на життя громадян і суспільства у цілому:

1) ринки та галузі економіки, де відбувається взаємодія конкретних суб'єктів;

2) цифрові платформи і технології, за допомогою яких формуються компетенції для розвитку ринків і галузей економіки;

3) середовище, яке створює умови для розвитку технологій i ефективної взаємодії суб'єктів ринків та галузей економіки й охоплює нормативне регулювання, інформаційну інфраструктуру, кадри та інформаційну безпеку.

Кінцевою метою нормативного регулювання цифрових економік $\epsilon$ формування нового регуляторного середовища, що забезпечує сприятливий правовий режим для виникнення i розвитку сучасних технологій, а також для здійснення економічної діяльності, пов'язаної 3 їх використанням (цифрової економіки). Для реалізації цієї мети необхідно в тому числі:

- створення окремих правових інститутів, спрямованих на вирішення першочергових завдань формування цифрової економіки;

- формування комплексного законодавчого регулювання відносин, що виникають у зв'язку з розвитком цифрової економіки;

- ужиття заходів, спрямованих на стимулювання економічної діяльності, пов'язаної з використанням сучасних технологій, збором і використанням даних. 
По суті, йдеться про якісно новий напрям розвитку правової системи, пов'язаний як із підтримкою вже існуючих наскрізних цифрових платформ і технологій, так i зі створенням умов для виникнення нових платформ та технологій.

Основними наскрізними цифровими технологіями, є великі дані (big data); нейротехнології і штучний інтелект; системи розподіленого реєстру; квантові технології; нові виробничі технології; промисловий Інтернет; компоненти робототехніки i сенсорика; технології бездротового зв'язку; технології віртуальної і доповненої реальності.

Головним способом забезпечення ефективності цифрової економіки стає впровадження технології обробки даних, що дасть змогу зменшити витрати під час виробництва товарів та надання послуг. Аналіз великих обсягів даних порівняно з традиційними формами людської діяльності дає величезні переваги: дає змогу підвищити ефективність різних видів виробництва, технологій, обладнання, зберігання, продажу, доставки товарів і послуг. Іншими словами, цифрова форма інформації, як і цифрова економіка, не тільки каталізує модернізацію людської діяльності, а й інтегрує багато сфер господарської та соціокультурної діяльності. Наприклад, упровадження новітніх технологій передачі даних дасть змогу створити мережі зв'язку п'ятого покоління, призначені для розвитку Інтернету речей і індустріального Інтернету.

Індустріальний Інтернет - це технологічна платформа підключення до мережі Інтернет промислових пристроїв, обладнання, датчиків, сенсорів, систем управління технологічними процесами, а також інтеграції даних програмно-апаратних засобів між собою без участі людини. На цій основі вже сьогодні працюють багато господарських комплексів. На побутовому рівні аналогічна технологічна платформа функціонує у формі Інтернету речей - обчислювальної мережі, що з'єднує речі (фізичні предмети) і дає їм можливість взаємодіяти один 3 одним або із зовнішнім середовищем без участі людини. Названі технології дають змогу в автоматизованому режимі управляти складними об'єктами господарської діяльності, що розширює можливості цифрової економіки.

Однак упровадження інфраструктури цифрової економіки тісно пов'язане із загрозами інформаційній безпеці. Конкурентною перевагою на світовому ринку мають держави, галузі економіки яких грунтуються на технологіях аналізу великих обсягів даних. Такі технології активно використовуються в Україні, але вони засновані на зарубіжних розробках. Вітчизняні аналоги, на жаль, відсутні. Ця обставина перешкоджає розвитку цифрової економіки.

Повсюдне впровадження закордонних IКТ, у тому числі на об'єктах критичної інформаційної інфраструктури (інформаційні системи та 
автоматизовані системи управління технологічними процесами, що функціонують в оборонній промисловості, у сфері охорони здоров'я, транспорту, зв'язку, кредитно-фінансовій сфері, енергетиці, паливної, атомної, ракетно-космічній, гірничодобувній, металургійній та хімічній промисловості), ускладнює забезпечення захисту інтересів громадян i держави в інформаційній сфері. 3 використанням мережі Інтернет усе частіше відбуваються кібератаки та інші посягання на державні та приватні інформаційні системи.

\section{2. Державне управління інформаційними викликами}

\section{в умовах турбулентності}

Поняття «турбулентність» у проекції на суспільні процеси з'явилося наприкінці $\mathrm{XX}$ століття після виявлення досить суворих закономірностей хаотичної поведінки не тільки фізичних, а й біологічних і «соціальних» об'єктів, економічних і політичних явищ. Представники соціальних і економічних наук почали вживати терміни «турбулентні часи», «турбулентний світ», «соціальна турбулентність», «турбулентний соціум» ${ }^{3,4,5,6,7}$.

Н.С. Розов, визначаючи епоху турбулентності як певний історичний період в історії людства, стверджує, що в Свропі таких періодів було шість $^{8}$. Кожна 3 епох турбулентності еволюціонувала за допомогою затвердження нового міжнародного порядку, нових принципів внутрішньополітичного устрою держав, поширення нових релігійних, соціальних, моральних цінностей. Нинішня криза глобальної стабільності вбачається в низці ознак економічного, політичного, воєнного, екологічного, інформаційного та інших гатунків.

Термін «турбулентність» походить від латинського turbulentus «бурхливий, хаотичний, невпорядкований». Його використання вказує

3 Гринберг Р.С. Основные проблемы современного турбулентного мира. Гуманитарий Юга России. 2013. № 2. С. 22-28.

4 Резеньков Д.Н., Приходько С.С. Понятие «социальная турбулентность» в современном мире в концепции информационной безопасности России. Культура $u$ общество: история и современность : материалы II Всероссийской (с международным участием) научно-практической конференции / под редакцией О.Ю. Колосовой и др. Ставрополь : Ветеран, 2013. С. 128-130.

5 Щекотин Е.В. Социальное управление в турбулентном обществе: вопросы безопасности и риска. Социчм и власть. 2016. № 1(57). С. 87-92.

6 Щекотин Е.В. Проблема благополучия в турбулентном социуме: аспект безопасности. Вестник науки Сибири. 2017. № 4(27). С. 74-83.

${ }^{7}$ Чудинов С.И., Щекотин Е.В. Турбулентный социум и концепция безопасности: социально-философские аспекты : монография. Новосибирск : НГТУ, 2018. 159 с.

${ }^{8}$ Розов Н.С. Эпохи турбулентности и их преодоление. Полития. 2019. № 1(92). C. 81-96. 
на переважання нелінійних процесів, хаотичність, непередбачуваність подій, різкі зміни тенденцій, зростання конфліктності. Під час розгляду суспільних відносин таке визначення може бути використане для аналізу «порушень соціального порядку». Згідно 3 класичним визначенням, соціальний порядок - система, що включає індивідів, взаємозв'язки між ними, урегульовані соціальними нормами (право, мораль, релігія тощо), що сприяють поведінці людей, необхідній для успішного функціонування цієї системи.

Очевидно, що епоха турбулентності повинна зачіпати як мінімум два рівня соціальних порядків: усередині держави (економічний, політичний, культурний, інформаційний) i порядок міжнародний, тобто формальні i неформальні правила взаємодії між державами. Окрім того, у відповідний концепт необхідно включити головні зовнішні прояви турбулентності: підвищення щільності конфліктів, у тому числі насильницьких, їх загострення і масштаб. Нарешті, епоха турбулентності має не тільки об'єктивний (кризи, конфлікти та інші деструктивні процеси), а й суб'єктивний аспект у вигляді масових проявів безвиході, втрати орієнтирів, відсутності видимих шляхів подолання негараздів.

Ураховуючи сказане, а також беручи до уваги попередні дослідження ${ }^{9,10,11,12}$, формулюємо таке визначення: епоха турбулентності- це історичний період, коли частішають і загострюються економічні та соціально-політичні конфлікти з характерним зростанням насильства у вигляді війн, революцій, тероризму; відчуття краху колишнього стабільного стану, бурхливих суперечливих емоцій (від утопічних надій до розгубленості і песимізму), що ведуть до істотного порушення психічного здоров'я населення, внутрішнього соціального порядку в державі, а також порядку та форм міжнародних відносин.

У соціальних науках концепт «турбулентність» важливий передусім як метафора для позначення різних форм нестійкості і невизначеності, які мають місце в сучасному світі. О.Н. Яницький, наприклад, дає таке визначення: «Турбулентність насправді означає крайню ступінь

9 Панченко О.А. Психологические аспекты турбулентности информационной среды. Причорноморські психологічні студї. 2017. Вип. 1. С. 3-7.

${ }^{10}$ Панченко О.А. Турбулентность в информационной безопасности личности. Клінічна інформатика і телемедицина. 2017. Т. 12. Вип. 13. С. 124-129.

${ }^{11}$ Панченко О.А. Психологическая турбулентность в условиях информационной войны. 2018. URL : http://www.psyh.kiev.ua/Панченко_О.А._Психологическая турбулентность_в_условиях_информационной_войны (дата обращения: 25.05.2020).

12 Панченко О.А., Сердюк I.А. Особистісні ті суспільні відносини в епоху турбулентності. Материаль Международной научно-практической интернетконференции «Тенденции и перспективы развития науки и образования в условиях глобализаиии», 28 февраля 2020 г. Переяслав, 2000. Вып. 56. С. 42-45. 
нестабільності світової економічної і політичної системи, коли ймовірність досягнення точки їі біфуркації i/aбо злому дуже висока» ${ }^{13}$. Виникнення критичної точки турбулентності пов'язане 3 низкою тенденцій сучасного світового розвитку, що супроводжується незворотними радикальними змінами - трансформацією. Виникає замкнуте коло, коли одне породжує інше, і навпаки. На підтвердження, беручи до уваги роботи інших дослідників ${ }^{14,15,16,17,18}$, можна виділили п’ять найбільш вагомих аргументів.

По-перше, суспільство, яке змінюється, $€$ перманентним генератором трансформації. Інновації можуть бути настільки відмінні від попередніх реалій, що приймаються людьми як шок. Джерелом збудження як причини турбулентності є передусім протистояння еліт у боротьбі за владу і політична «незадоволеність» населення. Особливо яскраво цей процес спостерігається під час виборів і зміни правлячих еліт. I саме держави 3 демократичною формою правління, яким властиві свобода слова і плюралізм, найбільш уразливі в плані виникнення турбулентності.

По-друге, турбулентні явища, пов'язані 3 глобалізацією та періодичними економічними кризами, докорінно змінюють світ. В умовах глобалізації він не став більш стабільним і передбачуваним. Навпаки, його головними характеристиками стали хаос і підвищений потенціал конфліктності. Поки економіка розвивається, настрій у суспільстві у цілому позитивний. Але у разі настання кризи, коли життєві стандарти різко знижуються, слідує різке невдоволення населення. I навіть розвиваючись, світова економіка нерівномірно розподіляе продукт свого розвитку. Багато держав, регіони, перебуваючи на «периферії», живуть на дотації «центру» або позикові кошти. Нерівномірно розподілений фінансовий капітал спричиняє

13 Яницкий О.Н. «Турбулентные времена» как проблема общества риска. Общественные науки и современность. 2011. № 6. С. 155-164.

${ }^{14}$ Social Turbulence and Governmental Form. 2016. URL : https://neociceroniantimes. wordpress.com/2016/11/09/social-turbulence-and-governmental-form/ (дата обращения: 25.05.2020).

15 Эстулин Д. Тавистокский институт / перевод П. Смирнова. Минск, 2014. URL : http://coollib.com/b/284081(дата обращения: 23.05.2020).

${ }^{16}$ Яницкий О.Н. Социобиотехнические системы: новый взгляд на взаимодействие человека и природы. Социологическая наука и сочиальная практика. 2016. № 3. C. 5-22.

17 Клименко С. Теория и практика ведения «гибридных войн» (по взглядам НАТО) 2015. Зарубежное военное обозрение 2015. № 5. С. 109-112.

18 Stepanova E. Terrorism in Asymmetrical Conflict: Ideological and Structural Aspects. SIPRI Research Report. 2008. № 23. URL : https://www.sipri.org/sites/default/ files/files/RR/SIPRIRR23.pdf (дата обращения: 25.05.2020). 
переміщення робочої сили (у тому числі і нелегальної), матеріалів, енергії. У таких умовах сталий розвиток стає більше ніж проблемним.

Глобалізація також породила трансформації відкритості і закритості соціуму. Раніше традиційне суспільство відрізнялося своїми «жорсткими» цінностями i нормами, які підтримувалися завдяки політичним і культурним межам. Ідеологи лібералізму розглядають відкритість кордонів соціуму як «універсальний» ідеал для всього людства. Однак його реалізація (на прикладі біженців) стала сьогодні шоком для багатьох європейців. Слід зазначити, що турбулентність генерується самим фактом різноманітності культур і життєвого укладу. Масове ж «нашестя» чужорідних культур вимагає від Європи все більших зусиль із підтримки «єдності в різноманітті» для запобігання міжнаціональним конфліктам.

Як це не парадоксально, в умовах відкритості виникають трансформації закритості у вигляді небачених раніше локальних сегрегацій i анклавних спільнот. За одним зі сценаріїв розвитку суспільства в умовах турбулентності - це його сегментація, коли кожна група - етнічна, расова, гендерна - воює проти всіх інших. Нації розпадаються на регіональні групи, які, своєю чергою, дробляться на ще більш дрібні етнічні групи заради спрощення процесу прийняття рішень. Природні лінії поділу суспільства перетворюються на барикади. Приклад - світова турбулентність у вигляді коронавірусу COVID-19, унаслідок якого Євросоюз фактично опинився у стані паралічу. Причина навіть не в тому, що були закриті кордони його держав-членів, а в тому, що кожна держава відособилася у своїх проблемах. I коли в Італії почався дефіцит медичних масок, апаратів штучного дихання, тестів на вірус і другого обладнання, вона не змогла закупити необхідне в інших країнах Свросоюзу. Держави закриваються і можуть розраховувати тільки на власне виробництво та зайнятість населення всередині держави.

Продовжуючи про некеровану відкритість, мусимо зазначити, що вона виробляє і небезпечні для соціуму трансформації в духовному житті, які виражені у зростаючому символічному насильстві, зумовленому комерціалізацією мас-медіа: сенсаційність, фейкові новини підмінили собою якісну аналітичну інформацію і мистецтво, а шоумейкери буквально витіснили 3 екранів освітні програми, затьмарили цінності сім'ї, навчання, праці. Це викликає соціальну тривогу і невизначеність.

По-трете, зміна взаємовідносин між людством і біосферою призвела до появи складних соціальних і техно-природних гібридів, як правило, глобального характеру. До недавнього часу людина вважала себе господарем природи. Однак сьогодні все більше свідчень того, що 
Біосфера (через природні аномалії і катастрофи) все частіше визначає поведінку людини і соціуму. Панування над природою змінюється проблемою збереження того, що людині вдалося досягти. Це підтверджує і О.Н. Яницький, говорячи, що звичний поділ на природу і суспільство більше не відповідає процесам стиснення й інтеграції всього того, що відбувається на Землі. Ми тепер живемо в соціобіотехносфері, іiі закони нами ще не досліджені. По суті, сталася низка трансформацій із природою, соціумом, технічними новаціями, які раніше являли самостійну реальність, а нині здебільшого утворюють єдине ціле. Одним із таких гібридів є вже наведений приклад пандемії коронавірусу COVID-19, яка струснула планету.

По-четверте, турбулентні світові тенденції відображають небезпечний характер розвитку подій, який характеризується трансформацією стирання роздільних ліній між станом війни і миру. Конкуруючі між собою сторони все частіше вдаються не до правових вирішень спорів, а інших засобів, що дає змогу комплексно впливати на розвиток кризової ситуації у своїх інтересах і при цьому створювати видимість неупередженості, приховуючи свою безпосередню залученість у протистояння.

Інструменти для досягнення стратегічних цілей, що включають політико-дипломатичні, інформаційно-психологічні, економічні та силові, визначаються як «неявні військові дії», «нелінійні», «асиметричні», «нетрадиційні» і «гібридні» операції. Узагальненим поняттям для позначення нової форми протиборства стало таке: гібридна війна - приховані агресивні дії, що йдуть урозріз із нормами міжнародного права.

По-n'яте, процес інформатизації світової системи, що сприймається як символ і індикатор прогресу, має декілька проблемних явищ, пов'язаних з інформаційними трансформаціями:

- процес вимагає більшої прозорості інформаційних відносин, а це неминуче призводить до порушення прав і свобод;

- прихід «постпаперової» культури істотно змінюе структуру i функції інститутів управління, освіти і науки;

- загострюється боротьба між глобальними гравцями за роль «програмістів» i «перемикачів» засобів масової інформації i комунікації, мережевих систем, за допомогою яких формується глобальна політика ${ }^{19}$.

${ }^{19}$ Панченко О.А. Роль засобів масової інформації в системі державного управління інформаційною безпекою. Публічне управління та митне адміністрування. 2020. № 1(24). C. 97-102. DOI : 10.32836/2310-9653-2020-1.19. http://customs-admin.umsf.in.ua/ archive/2020/1/19.pdf. 
Для подальшого розгляду наведемо ще одне визначення ${ }^{20}$ : соціальний порядок - стан відносної стабільності, врівноваженості, збалансованості соціальних відносин, діяльності, норм у суспільстві, який задає індивідам, групам, інституціям відповідні моделі поведінки. Соціальний порядок є статичною, емерджентною характеристикою соціальної системи, що інтегрує у собі ії цілісність, організованість, гармонійність, унормованість, або структурну, інституціональну, організаційну, функціональну, нормативну впорядкованість. У соціальному порядку, незважаючи на системність, залежно від площини розгляду можна виділити його форми: структурний, інституціональний, організаційний, функціональний, нормативний та ін.

До розгляду взятий функціональний порядок, адже він фігурує як основний (дивись перше визначення) у суспільних відносинах, він перебуває у найбільш динамічному стані, і саме тому він найбільше віддзеркалює риси епохи турбулентності. Відомий соціологфункціоналіст Артур Стінчкомб ${ }^{21}$ за допомогою математичного апарату запропонував оригінальну концепцію пояснення соціальних явищ, де функціональний порядок визначається динамічною взаємодією декількох змінних. Використовуючи його методологію, можна відобразити універсальну модель підтримки рівноваги стану динамічної системи, у тому числі соціального типу (рис. 1).

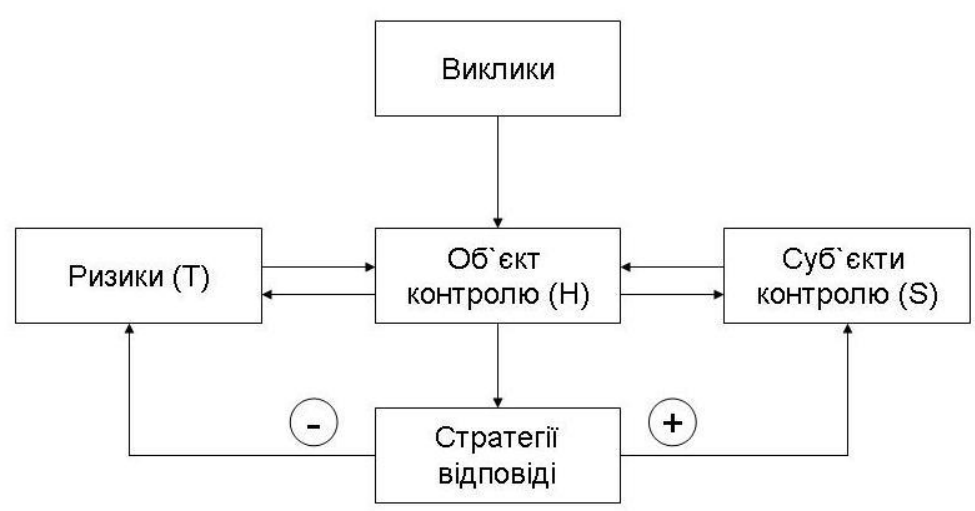

\section{Рис. 1. Модель підтримки рівноваги стану динамічної системи}

${ }^{20}$ Соціологія: короткий енциклопедичний словник. URL : https://subject.com.ua/ sociology/dict/422.html (дата звернення: 25.05.2020).

${ }^{21}$ Stinchcombe A. Constructing Social Theories. Chicago : University of Chicago Press, 1987. $320 \mathrm{p}$. 
В основі функціональної схеми А. Стінчкомба лежать три елементи: 1) основна, гомеостатична змінна $\mathbf{H}$, яка знаходиться в рівновазі (на рис. 1 - об'єкт контролю) й яка, власне, відображає явище; 2) структура підтримки $\mathbf{S}$ (суб'єкти контролю), яка допомагає зберігати стабільність Н і пов'язана з нею прямим і зворотним зв'язком; 3) напруга $\mathbf{T}$ (ризики) - те, що прагне порушити рівновагу і негативно впливає на Н. Суть роботи класичної схеми дуже проста. Розглядаються впливи на змінну Н. Якщо структура підтримки S1 справляється із завданням стабілізації Н на заданому рівні, виникає нова $\mathbf{S 2}$, яка залежно від наявних ресурсів і нових умов буде по-іншому впливати на Н і яка, своєю чергою, може бути пов'язана з іншими $\mathbf{H i . ~}$

У розглянутій моделі (рис. 1) було зроблено деякі поправки i доповнення. По-перше, у класичній схемі від $\mathbf{H}$ до $\mathbf{T}$ немає зворотного зв'язку, тільки «негативна» стрілка від $\mathbf{T}$ до Н. Погоджуючись 3 думкою Н.В. Головко 22 , якщо зв'язати Н і Т зворотним зв'язком, можна отримати додаткові важелі в поясненні деяких суспільних тенденцій. Чим сильніше тисне $\mathbf{T}$, тим менше значення $\mathbf{H}$, тим більше зусилля докладає $\mathbf{S}$ для того, щоб відновити значення $\mathbf{H} . \mathbf{S}$ і $\mathbf{T}$ формально отримують однаковий статус взаємно протидіючих «сил», пов'язаних прямим і зворотним зв'язком із Н. У певному сенсі тут можна говорити про рівнозначність $\mathbf{T}$ і $\mathbf{S}$ : важливо не те, що структура підтримки знімає негативний ефект напруги, a те, що відновлення значення гомеостатичної змінної одночасно створює умови для порушення іiі балансу,

По-друге, вводимо елементи «виклики» і «стратегії». Це дає змогу зробити модель більш універсальною, адже ризики для об'єкта турботи виникають тільки за наявності викликів. А стратегії - це реагування на виклики. Вони можуть бути успішними і вести до зменшення ризиків за рахунок покращення контролю суб'єктів, а можуть бути i негативними - тоді підсилюються ризики.

Запропонована модель пояснює причини порушення стабільності будь-якої системи, оскільки вказує на різні варіанти можливої конфігурації:

- поява нових незвичних викликів i ризиків (зовнішніх i внутрішніх);

- провал колишніх суб'єктів контролю (інститутів, організацій, практик), надмірні витрати і незаплановані негативні наслідки їхньої діяльності;

22 Головко Н.В. Предпринимательский университет и функционализм А. Стинчкомба. Вестник Новосибирского государственного университета. Серия «Философия». 2014. Т. 12. Вып. 3. С. 53-61. 
- неадекватні стратегії відповіді на виклики;

- нерелевантність об'єктів контролю, виражених через цінності, принципи і правила, умовам, що змінилися.

До явищ, які зазвичай включаються у зміст нинішньої кризи глобальної стабільності, можна віднести:

1) затяжні військові конфлікти, формування зон насильства i соціальних лих, багаторічні зусилля з подолання яких досі не принесли результату (арабо-ізраїльський конфлікт, Сирія, Лівія, Донбас та ін.);

2) зростання напруженості між країнами-лідерами, конфлікти всередині Євросоюзу;

3) тероризм, загрози з боку міжнародних кримінальних спільнот i мереж;

4) міграційна криза в Європі, майже повсюдне зростання ксенофобії, зрушення в напрямі політики закритих дверей та протекціонізму;

5) істотне зниження авторитету, ролі, впливу ООН, ЮНЕСКО та інших міжнародних організацій;

6) глобалізацію економічних криз, посилення соціальних протестів, революційні хвилі;

7) розчарування в демократії, зліт популярності авторитарних лідерів, установлення популістських режимів;

8) почастішання природних катаклізмів, для подолання яких часто не вистачає ресурсів;

9) негативні тенденції, що пов'язані 3 новітніми інформаційними викликами.

Насамперед необхідно зазначити, що сформований у сучасній соціології погляд на турбулентність можна охарактеризувати як «стурбованість» - турбулентність оцінюється як деякий системний виклик, як тимчасовий стан транскордонного переходу до більш стабільного стану.

Можливо, що сьогоднішні нестабільність і нестійкість - це саме риси найближчого майбутнього, в якому нам доведеться жити. Констатація турбулентності сучасного суспільства ставить низку серйозних завдань перед управлінням (суб'єктами контролю згідно з рис. 1). Щодо останнього у контексті даного дослідження потрібно надати деякі пояснення. Насамперед, управління - поняття складне й багатогранне, воно залежить від специфіки об’єкта. За визначенням В.М. Соловйова, у загальному розумінні управління - це цілеспрямований вплив на складну систему ${ }^{23}$. У більш конкретному розумінні управління, на

23 Соловйов В.М. Поняття і сутність правового регулювання державного управління в Україні. Університетські наукові записки. 2007. № 3(23). С. 27-33. 
думку В.П. Пилипишина ${ }^{24}$, являє собою діяльність уповноважених органів, що спрямована на досягнення конкретних завдань за допомогою управлінських методів, способів та функцій.

Розглядаючи управління через призму держави, звернемо увагу на одну особливість: справа в тому, що зміст терміна «управління» у цьому разі можна інтерпретувати двояко: управління держави, коли остання виступає суб'єктом діяльності щодо виконання законів та інших правових актів органів державної влади, і державне управління, яке розглядається як один із видів соціального в дотриманні суспільного порядку й $є$ особливою функцією, що виникає з потреб суспільства як самодостатньої системи та здійснюється у відповідних державних чи недержавних формах шляхом організаторської діяльності спеціально створеної для цього групи органів. Таке управління має також політичний характер, може розглядатися 3 соціального, економічного погляду. Саме у цій інтерпретації ми розглядаємо державне управління в нашій моделі. Головне, що пріоритетами діяльності демократичної держави повинно бути забезпечення реалізації прав, свобод і законних інтересів іiі населення, служіння йому. У зв'язку із цим система державного управління повинна бути близькою до потреб i запитів простих людей, підконтрольною суспільству, прозорою та ефективною.

Сформувавши всі компоненти моделі в загальному вигляді, переходимо до розгляду іiі роботи під час конкретизації інформаційних викликів. До розгляду взято два варіанти: 1) турбулентні інформаційні виклики державі; 2) турбулентні інформаційні виклики особистості. Виходячи $з$ логічного міркування, у першому випадку об'єктом буде інформаційна безпека держави, у другому - інформаційнопсихологічна безпека особистості.

Державне управління безпекою передбачає не тільки розрахуноквимір ризиків, а й зниження та управління ними. Рівень того чи іншого ризику кількісно характеризує ефективність прийнятих заходів безпеки. Діяльність з їх планування та здійснення $є$ безпосередньою функцією державного управління. Тому, на нашу думку, закономірно трактувати рівень захищеності населення від впливу інформаційних ризиків, рівень забезпечення інформаційної безпеки як критерій оцінки ефективності управління.

Із погляду державницького підходу під інформаційною безпекою розуміється стан захищеності національних інтересів в інформаційній сфері за збалансованості потреб особистості, суспільства і держави.

\footnotetext{
${ }^{24}$ Пилипишин В.П. Поняття та основні риси державного управління. Юридична наука і практика. 2011. № 2. С. 10-14.
} 
Більш загальне визначення дає Р.М. Юсупов. Він стверджує, що «...інформаційна безпека відповідного суб'єкта (особистості, суспільства, держави, будь-якої системи) може бути визначена як стан, в якому йому (суб'єкту) не може бути завдано істотної шкоди шляхом впливу на його інформаційну сферу» ${ }^{25}$.

За нашими дослідженнями ${ }^{26,27,28}$ інформаційна безпека - «здатність держави, суспільства, соціальної групи, особистості, по-перше, забезпечити з певною ймовірністю достатні і захищені соціальний інтелект та інформаційний ресурс, оптимальну соціальну ентропію й інформаційне середовище для підтримки життєдіяльності i життєздатності, стійкого функціонування і розвитку соціуму; по-друге, протистояти інформаційним небезпекам i загрозам, негативним інформаційним впливам на індивідуальну і суспільну свідомість та психіку людей, а також на комп'ютерні мережі й інші технічні джерела інформації; по-трете, виробляти особистісні та групові навички та вміння безпечної поведінки; по-четверте, підтримувати постійну готовність до адекватних заходів в інформаційному протиборстві, ким би воно не було нав'язане; по-п'яте, постійно і послідовно за певною безпечною програмою «вмонтувати» штучний інтелект у суспільне середовище».

Вибираючи стратегії, мусимо визнати, що тут провідна роль належить державі. Хоча ми у своїх попередніх дослідженнях наголошували на значущій ролі особистості в іiі інформаційно-психологічній безпеці за рахунок стратегій формування відповідної особистісної інформаційної культури та «турбулентного мислення»: мислення, засноване на неформальному, евристичному підході до аналізу ситуації і прийняття рішень (досвід, інтуїція, винахідливість і т.д.) ${ }^{29}$.

Як стратегію в моделі (див. рис. 1) нами вибрано забезпечення інформаційно-иифрового суверенітету держави. Елементами традиційного суверенітету $є$ воєнний, економічний, політичний,

25 Юсупов Р.М. Информационное обеспечение национальной безопасности. Национальная безопасность. 2010. № 7/8. С. 87.

26 Панченко О.А. Проблеми правового забезпечення державного управління інформаційною безпекою. Державне управління: удосконалення та розвиток. 2019. № 11. DOI : 10.32702/2307-2156-2019.11.3. http://www.dy.nayka.com.ua/?op=1\&z=1561.

27 Панченко О.А. Інформаційна безпека держави як елемент соціальної культури. Аспекти публічного управління. 2020. № 1. Т. 8. С. 58-67. URL : https://aspects.org.ua/index.php/journal/article/view/720/692.

28 Панченко О.А. Суспільний запит на інформаційну безпеку. Публічне урядування. № 2(22). С. 141-149. DOI : 10.32689/2617-2224-2020-2(22)-141-149. URL : https://vadnd.org.ua/app/uploads/2015/09/Публічне-урядування_222_англ-2.pdf.

29 Панченко О.А. Турбулентність мислення в структурі інформаційнопсихологічної безпеки особистості. Психологія і особистість. 2019. № 1(15). С. 35-53. 
культурно-ідеологічний компоненти. До них в останні роки приєднався новий - інформаційно-цифровий. В епоху турбулентності відбувається «розмиття» рамок суверенітетів, а відсутність інформаційно-цифрового може призвести до втрати суверенітету держави взагалі.

Вибрана стратегія означає, що держава повинна мати такі права i можливості:

- самостійно визначати національні інтереси у цифровій сфері;

- самостійно вести внутрішню і зовнішню інформаційну політику;

- володіти власними інформаційними ресурсами і розвивати інформаційну інфраструктуру держави;

- контролювати електронну та інформаційну безпеку держави.

На основі цього держава, виконуючи свої функції, забезпечує:

1. «Стійкість» до дій кіберагресора: захист від руйнування інфраструктури, вірусів, атак, зломів, витоків, крадіжки даних, спаму; стійкість до електронних атак (моніторинг, виявлення, попередження, блокування, контратаки).

2. «Стійкість» до умов інформаційної війни: самостійне управління інформацією (фільтрація інформаційних потоків, поширення інформації та ін.); стійкість до інформаційних атак (можливості виявлення, попередження, блокування інформації та контратаки).

Інформаційно-цифровий суверенітет держави охоплює два важливі напрями.

1. Медійна інфраструктура, до складу якої входять: пошукові машини, довідкові ресурси; соціальні мережі, месенджери, блоги, форуми, розсилки; Інтернет-ЗМІ, традиційні ЗМІ і ТБ; відеохостинги і фотохостинги; тематичні ресурси (рейтинги/аналітика, історія, наука, автомобілі, спорт, кіно, книги); додатки для соціальних мереж i мобільних пристроїв; дитячий Інтернет.

2. Засоби пропаганди та інформаційних війн: аналіз медійного середовища, моніторинг трафіку і соціальних медіа; кошти фільтрації трафіку; законодавство про відповідальність за контент (хостерів, провайдерів доступу та медійних провайдерів); кошти поширення контенту: ЗМІ, блоги, соціальні мережі; сили для поширення контенту: спеціальні підрозділи і засоби для інформаційних війн в мережі ${ }^{30}$.

Окремим важливим елементом інформаційно-цифрового суверенітету є сфера ідеологічної роботи. Наскільки суверенітет держави забезпечується ідеями і наскільки вони конкурентоспроможні- ці

${ }^{30}$ Панченко О.А. Засоби масової інформації як джерело інформаційної безпеки. Експерт: парадигми юридичних наук $i$ державного управління. 2020. № 2(8) C. 250-258. DOI: 10.32689/2617-9660-2020-2(8)-250-258. URL : http://maup.com.ua/ assets/files/expert/8/21.pdf. 
чинники стають вирішальними у забезпеченні не тільки інформаційної а й узагалі безпеки держави.

Переходячи до другого варіанту (турбулентні інформаційні виклики особистості), підкреслимо, що у цьому напрямі нами проведено досить масштабні дослідження, результати яких відображено у відповідних наукових працях. У проекції на модель, що розглядається, основним ризиком $\epsilon$ турбулентність інформаційного середовища, яка породжує явище інформаційно-психологчної турбулентності: нестабільний стан психіки людини, викликаний інформаційним впливом, що виявляється у раптових припливах гніву, печалі або відчаю, відчутті тривоги, роздратування, страху чи смутку. У такому стані особистість неадекватно оцінює навколишнє оточення і робить нелогічні вчинки.

Побічним супроводжуючим негативним процесом $\epsilon$ вплив кіберпростору. За словами I.С. Ашманова ${ }^{31}$, користувачі «стрімко дурнішають». У Твіттері, Фейсбуці немає «пам'яті», контент тоне в швидкості змін різноманіття інформації. Мислення користувача стає кліповим. Зростають жорстокість і поляризація думок, підвищується градус дискусій. В Інтернеті втрачаються цінності та норми: вкидання дезінформації, обман, пропаганда, спам стають звичайними практиками. У соціальних мережах активно оперують професіонали, у тому числі спільноти «спамерів», діють технологічні системи «відмивання» новин та інформаційних вкидань.

Формуючи далі модель, виходячи 3 попереднього, об'єктом небезпечного інформаційного впливу i, отже, інформаційної безпеки можуть виступати свідомість та психіка особистості.

Щодо суб'єктів інформаційної безпеки, то такими слід уважати ті органи i структури, які тією чи іншою мірою займаються іiі забезпеченням. Особистість також може виступати суб'єктом, хоча й займає при цьому найбільш уразливу позицію у забезпеченні своєї інформаційної безпеки, адже вона $\epsilon$ складовою частиною самої біосоціальної системи, що підлягає захисту (людина, іiі психіка, моральний i духовний світ, соціально-політичні, психологічні орієнтації, установки, відносини, раціональні та ірраціональні аспекти поведінки, системи громадської думки і прийняття рішень).

Державна стратегія інформаційної безпеки має передбачати, насамперед, виконання базових принципів іiі втілення. Одним із найважливіших $є$ принцип балансу інтересів особистості, суспільства $\mathrm{i}$ держави. Очевидно, що особистість зацікавлена в конфіденційності інформації про інтимне життя, доходи, і т. д. Але суспільство

31 Ашманов И. Цифровой суверенитет - новая реальность. 2013. URL : http://eurasian-defence.ru/sites/default/files/doc/ashmanov.pdf (дата обращения: 25.05.2020). 
зацікавлене в інформації про антисоціальні прояви, корупцію, і т. д. Державні органи взагалі хотіли б знати все про громадян.

Другий принцип - це принцип законності і правої забезпеченості. Зростання значущості інформаційної безпеки явно випереджає розвиток відповідної сфери права, чим уміло користуються і політики, $\mathrm{i}$ засоби масової інформації, і просто шахраї.

Третій - держава по відношенню до особистості має виконувати більш партнерські, а не насильницькі функції.

\section{ВИСНОВКИ}

Сьогодні державна інформаційна політика набуває стану найважливішого складника зовнішньої і внутрішньої політики країни, а побудова демократичного інформаційного суспільства і входження країни у світове інформаційне співтовариство $\epsilon$ довгостроковою стратегічною метою. Причинами цього $\epsilon$ стрімкий розвиток інформаційного суспільства та глобалізація медійного простору, а також настання епохи турбулентності, інформаційних війн i протистояння у боротьбі за вплив на свідомість людини.

Виходячи із цього, можна виділити напрями, на які слід зробити акцент для здійснення грамотної державної інформаційної політики у сучасних реаліях:

- розвиток громадянського суспільства;

- забезпечення конструктивного діалогу між державою, ЗМІ та суспільством;

- визнання презумпції відкритості інформації для громадян i захист їхніх інформаційних прав;

- орієнтація головних компонентів інформаційного простору на забезпечення вільного обігу інформації, втілення у життя конституційного права на вільний пошук, отримання, виробництво інформації та ії поширення;

- підвищення довіри суспільства до влади;

- налагодження ефективних взаємовідносин держави на міжнародній арені.

Головною трансформацією сучасного цифрового суспільства $€$ перетворення його в турбулентний стан, де основною ознакою $є$ потокова реальність, і в силу цього суспільство пронизане хаотичними, неконтрольованими процесами. Ці турбулентні явища можуть призвести як до нових революційних змін і відкриття альтернативних можливостей для людини, так і до катастрофічних наслідків.

Нестабільне середовище продукує як високі ризики, так і високі шанси для держави не втратити управлінські функції. Важливим 
завданням є інвентаризація досягнутого, розуміння нових реалій i вироблення відповідної державної політики.

Варіантом вирішення проблеми може стати симбіоз делегування широких повноважень на локальний рівень за належного контролю центру і «культури безпеки» як форми реалізації турботи про себе. Розвиток культури безпеки передбачає кілька важливих кроків - це зміцнення громадянської свідомості, посилення локальних спільнот і розширення певних прав громадян, пов'язаних із самозахистом, самоактуалізацією та особистою відповідальністю за теперішнє i майбутнє.

Запропонована авторська модель підтримки рівноваги стану динамічної системи дає змогу окреслити ризики викликів епохи турбулентності та сформувати стратегічні напрями державної інформаційної політики.

На прикладі розгляду інформаційних викликів державі та особистості підтверджена ефективність застосування моделі для вироблення дієвих стратегій забезпечення інформаційної безпеки в державному управлінні.

\section{АНОТАЦІЯ}

Із розвитком технологій та швидкості передачі даних у постіндустріальному суспільстві збільшується роль і значення інформації. Це визначило необхідність створення державами системи управління у галузі інформації або державної інформаційної політики. Державна інформаційна політика - важливий аспект державного управління в інформаційному суспільстві. Існують різні інститути, через які реалізуються заходи державної інформаційної політики. До них можна віднести інститути зв'язку з громадськістю, аналітичні центри, інститути культури.

Розвиток технологій збору й аналізу даних, обміну ними, управління виробничими процесами здійснюється на основі впровадження когнітивних технологій, їх конвергенції 3 нано- i біотехнологіями. Значне збільшення обсягу даних, джерелами i засобами поширення яких $є$ промислові та соціальні об'єкти, різні електронні пристрої, призводить до формування нового рівня наукомістких інформаційних технологій. Їх повсюдне застосування сприяє переходу до цифрової економіки.

Головним способом забезпечення ефективності цифрової економіки стає впровадження технології обробки даних, що дасть змогу зменшити витрати під час виробництва товарів та надання послуг. Аналіз великих обсягів даних порівняно з традиційними формами людської діяльності дає величезні переваги: дає змогу підвищити ефективність різних видів 
виробництва, технологій, обладнання, зберігання, продажу, доставки товарів і послуг. Іншими словами, цифрова форма інформації, як i цифрова економіка, не тільки каталізує модернізацію людської діяльності, а й інтегрує багато сфер господарської та соціокультурної діяльності.

\section{ЛITЕРАТУРА}

1. Могилевский В.Д. Методология систем: вербальный подход. Москва : Экономика, 1999. 251 с.

2. Винер Н. Кибернетика и общество. Москва : Изд-во иностр. лит., 1958. $200 \mathrm{c}$.

3. Гринберг Р.С. Основные проблемы современного турбулентного мира. Гуманитарий Юга России. 2013. № 2. С. 22-28.

4. Резеньков Д.Н., Приходько С.С. Понятие «социальная турбулентность» в современном мире в концепции информационной безопасности России. Культура и общество: история и современность : материалы II Всероссийской (с международным участием) научнопрактической конференции / под ред. О.Ю. Колосовой и др. Ставрополь : Ветеран, 2013. С. 128-130.

5. Щекотин Е.В. Социальное управление в турбулентном обществе: вопросы безопасности и риска. Социум и власть. 2016. № 1(57). C. $87-92$.

6. Щекотин Е.В. Проблема благополучия в турбулентном социуме: аспект безопасности. Вестник науки Сибири. 2017. № 4 (27). С. 74-83.

7. Чудинов С.И., Щекотин Е. В. Турбулентный социум и концепция безопасности: социально-философские аспекты: монография. Новосибирск : НГТУ, 2018. 159 с.

8. Розов Н.С. Эпохи турбулентности и их преодоление. Полития. 2019. № 1(92). С. 81-96.

9. Панченко О.А. Психологические аспекты турбулентности информационной среды. Причорноморські психологічні студіі. 2017. Вип. 1. С. 3-7.

10. Панченко О.А. Турбулентность в информационной безопасности личности. Клінічна інформатика і телемедицина. 2017. Т. 12. Вип. 13. C. $124-129$.

11. Панченко О.А. Психологическая турбулентность в условиях информационной войны. 2018. URL : http://www.psyh.kiev.ua/ Панченко_О.А._Психологическая_турбулентность_в_условиях_инфор мационной_войны (дата обращения: 25.05.2020).

12. Панченко О.А., Сердюк І.А. Особистісні ті суспільні відносини в епоху турбулентності. Материаль Международной научнопрактической интернет-конференциии «Тенденции и перспективы 
развития науки и образования в условиях глобализаџии», 28 февраля 2020 г. Переяслав, 2000. Вып. 56. С. 42-45.

13. Яницкий О.Н. «Турбулентные времена» как проблема общества риска. Общественные науки и современность. 2011. № 6. С. 155-164.

14. Social Turbulence and Governmental Form. 2016. URL : https://neociceroniantimes.wordpress.com/2016/11/09/social-turbulenceand-governmental-form/ (дата обращения: 25.05.2020).

15. Даниэль Эстулин. Тавистокский институт / перевод П. Смирнова. Минск, 2014. URL : http://coollib.com/b/284081(дата обращения: 25.05.2020).

16. Яницкий О.Н. Социобиотехнические системы: новый взгляд на взаимодействие человека и природы. Социологическая наука $u$ сочиальная практика. 2016. № 3. С. 5-22.

17. Клименко С. Теория и практика ведения «гибридных войн» (по взглядам НАТО) 2015. Зарубежное военное обозрение. 2015. № 5. C. $109-112$.

18. Stepanova E. Terrorism in Asymmetrical Conflict: Ideological and Structural Aspects. SIPRI Research Report. 2008. № 23. URL : https://www.sipri.org/sites/default/files/files/RR/SIPRIRR23.pdf (дата обращения: 25.05.2020).

19. Панченко О.А. Роль засобів масової інформації в системі державного управління інформаційною безпекою. Публічне управління та митне адміністрування. 2020. № 1(24). C. 97-102. DOI : 10.32836/2310-9653-2020-1.19. URL : http://customs-admin.umsf.in.ua/ archive/2020/1/19.pdf.

20. Соціологія: короткий енциклопедичний словник. URL : https://subject.com.ua/sociology/dict/422.html (дата звернення: 25.05.2020).

21. Stinchcombe A. Constructing Social Theories. Chicago : University of Chicago Press, 1987. 320 p.

22. Головко Н.В. Предпринимательский университет и функционализм А. Стинчкомба. Вестник Новосибирского государственного университета. Серия «Философия». 2014. Т. 12. вып. 3. С. 53-61.

23. Соловйов В.М. Поняття i сутність правового регулювання державного управління в Україні. Університетські наукові записки. 2007. № 3(23). С. 27-33.

24. Пилипишин В.П. Поняття та основні риси державного управління. Юридична наука і практика. 2011. № 2. С. 10-14.

25. Юсупов Р.М. Информационное обеспечение национальной безопасности. Национальная безопасность. 2010. № 7/8. С. 87.

26. Панченко О.А. Проблеми правового забезпечення державного управління інформаційною безпекою. Державне управління: 
удосконалення та розвиток. 2009. № 11. DOI : 10.32702/2307-21562019.11.3. URL : http://www.dy.nayka.com.ua/?op=1\&z=1561.

27. Панченко О.А. Інформаційна безпека держави як елемент соціальної культури. Аспекти публічного управління. 2020. № 1. Т. 8. C. 58-67. URL : https://aspects.org.ua/index.php/journal/article/view/720/692.

28. Панченко О.А. Суспільний запит на інформаційну безпеку. Публічне урядування. № 2(22). C. 141-149. DOI : 10.32689/2617-22242020-2(22)-141-149. URL : https://vadnd.org.ua/app/uploads/2015/09/ Публічне-урядування_222_англ-2.pdf.

29. Панченко О.А. Турбулентність мислення в структурі інформаційно-психологічної безпеки особистості. Психологія $i$ особистість. 2019. № 1(15). С. 35-53.

30. Панченко О.А. Засоби масової інформації як джерело інформаційної безпеки. Експерт: парадигми юридичних наук $i$ державного управління. 2020. № 2(8) C. 250-258. DOI : 10.32689/26179660-2020-2(8)-250-258. URL : http://maup.com.ua/assets/files/expert/ 8/21.pdf.

31. Ашманов И. Цифровой суверенитет - новая реальность. 2013. URL : http://eurasian-defence.ru/sites/default/files/doc/ashmanov.pdf (дата обращения: 25.05.2020).

\section{Information about author: \\ Panchenko O. A.,}

Doctor of Medicine, Professor, Honored Doctor of Ukraine, Director of the State Institution "Scientific - Practical Medical Rehabilitating Diagnostic Center of the Ukrainian Ministry of Health", President of the All-Ukrainian Professional Psychiatric League 14, Ol. Nevskoho Str., Kostiantynivka, Donetsk region, 85110, Ukraine https//orcid.org/0000-0001-9673-6685 